\title{
Analysis of spring water quality in Ebonyi South Zone and its health impact
}

\author{
1J.N. Afiukwa and ${ }^{2}$ A.N. Eboatu \\ ${ }^{1}$ Department of Industrial Chemistry, Ebonyi State University \\ Private Mail Bag 053, Abakaliki, Nigeria \\ ${ }^{2}$ Department of Pure and Industrial Chemistry, Nnamdi Azikiwe University, Awka, \\ Anambra State, Nigeria.
}

\begin{abstract}
Studies were carried out between June through December, 2007 to evaluate the quality of rural water supply for drinking in Ebonyi South Zone of Ebonyi State, Nigeria. The rural communities of Ekoli Edda and Ozizza in Afikpo South L.G.A and parts of Okposi in Ohaozara L.G.A depend solely on spring water for their domestic needs. Samples from seven spring water sources in these areas were analyzed for some physico-chemical and microbial parameters by standard methods. Concentrations of some heavy metals; $\mathrm{Cr}, \mathrm{Cd}, \mathrm{Co}, \mathrm{Cu}, \mathrm{Fe}, \mathrm{Mn}, \mathrm{Pb}, \mathrm{Ni}$ and $\mathrm{Zn}$ were determined using Atomic Absorption Spectrophotometer. The results of the chemical analysis compared favourably with the WHO standard for drinking water, except for the relatively high concentration of iron in samples SE $5(0.79 \mathrm{mg} / \mathrm{L})$ and SE $6(0.58 \mathrm{mg} / \mathrm{L})$, and the exceedingly high phosphate concentrations, ranging from $0.25-1.6 \mathrm{mg} / \mathrm{L}$ in all the samples as against the WHO permissible limit of $0.1 \mathrm{mg} / \mathrm{L}$. The bacteriological analyses however revealed about $40 \%$ total coliform bacteria contamination, varying between $0-4 \mathrm{MPN} / 100 \mathrm{ml}$ of water in five out of the seven samples tested. The mean total hardness ranged from $8-26 \mathrm{mgCaCO}_{3} / \mathrm{L}$ indicating that the water is soft. The pH ranged from $4.2-5.6$ and $4.5-6.0$ at the rainy and dry seasons respectively, with an average $\mathrm{pH}$ of $5.1 \pm 0.48$ during the rainy seasons and $5.6 \pm 0.58$ at the dry seasons. This study provides baseline information on the spring water situation in Ebonyi South and suggested an alternative method of harnessing the natural water.
\end{abstract}

\section{Keywords: Spring Water, Rural Community, Pollution and Public Health.}

\section{INTRODUCTION}

The Ekoli Edda, Ozizza and Ohaozara areas of Ebonyi South Zone are rural Communities in Ebonyi State, dependent on groundwater as the main alternative water supply for domestic uses. The land summit of Ekoli Edda are underlain by shale/sandstone and hard bedrock and only spring sources supply their water needs. Natural weathering of these rocks and run-off from the mountains are common phenomenon. Sinking of boreholes in Ekoli was aborted by the hard sedimentary rocks but the existence of several springs suggests a shallow water table in the bedrock. Irrespective of the fair distribution of the springs, provision of potable water to meet the need remains an unsolved problem especially in Ekoli Edda. In order to ensure a safe public health, water supply for human consumption must be free from pathogens, free from chemical toxins and must be physically clear and appealing to taste (WHO, 1973). It is also important that water for domestic, agricultural or industrial uses should not be acidic or alkaline than is required by standards for the purpose. Therefore the focus of this study is to determine the potability of the spring water by assessing the levels of some limiting physicochemical and microbial parameters, which justifies the quality of a drinking water.

Physical features of the springs: The study area is drained by the Cross River system, which is the main inland water source that recharges the aquifer. The ecosystem of the study areas is complex with varying species of plants, wildlife, undulating Rocky Mountains and thick forest reserves especially in Ekoli Edda. The spring water is accessed at the valley of the hills from man-made or natural cavity. Some are tapped directly from the exuding sources with zinc-shaped cone such as the lyi Anyaoji, Fig. 1. 


\section{MATERIALS AND METHODS}

The methods adopted for this study were field investigation/sampling and laboratory analyses. Sampling was carried out in the Months of June through December, 2007 and analyzed for metals at the Nigeria National Petroleum Corporation (NNPC) Warri, Delta State.

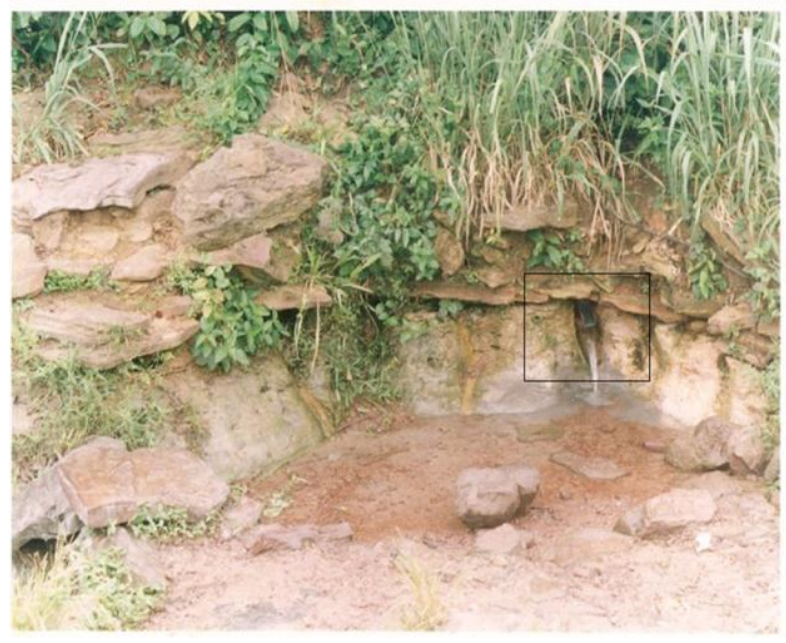

Fig.1: Typical sample site at Ekoli Edda, lyi Anyaoji, pH $4.3-5.5$

Some of the parameters such as temperature, $\mathrm{pH}$, Total Dissolved Solids (TDS), Electrical Conductivity (EC), Total Solids (TS), Dissolved Oxygen (DO), Colour and Turbidity were determined on site using portable HANNA Test Kits (Miroslav and Vladimir, (1999). The samples were collected in sterilized white polyethylene bottles previously rinsed with deionised water and preserved with a $0.2 \mathrm{M} \mathrm{HNO}_{3}$ to immobilize the metals against surface adsorption. Treated glass bottles were used to collect samples required for the determination of dissolved oxygen (DO), odour, biochemical oxygen demand, BOD and salinity. The $\mathrm{pH}$ and temperature were analysed using a dual probe pH-Meter (pHep HI 98127ATC), while colour was assessed using a BDH Lovinbond Colour
Tintometer, England make. The metals were analysed using Perkin Elmer A Analyst 400 Model Atomic Absorption Spectrophotometer, while anions were analyzed using a UV-Visible Spectrophotometer, (ASTM EZ 201, Perkin Elmer, Landa Model). The TDS was measured using the HANNA HI 98301 instruments, while HANNA HI 98303 and $\mathrm{HI} 9142$ ATC dissolved oxygen meter were used to measure conductivity and DO respectively. Total alkalinity and hardness were measured by titrimetric methods. The Multiple Fermentation Tube technique was applied for total coliform determination. The test samples were coded as lyi Anyaoji Ekoli (SE 1), lyi Nneoji Ekoli (SE 2), lyi Imminika Ekoli (SE 3), Ogwu Nwankpuma Ohaozara (SE 4), Ogwu Nwokereke Ohaozara (SE 5), Ekeje Spring Ozizza (SE 6) and Whyworry Spring Ozizza (SE 7).

\section{RESULTS AND DISCUSSION}

The levels of some trace metals, non-metals, physico-chemical and biological parameters in the spring water supply were compared with the WHO, 1997 guideline limits for drinking water to establish if the spring water is safe for human consumption. Results showed that the average concentrations of $\mathrm{Ca}(3.60 \pm 2.9-4.17 \pm 2.97 \mathrm{mg} / \mathrm{L})$ and $\mathrm{Mg}(1.04 \pm 0.86$ $-3.35 \pm 3.7 \mathrm{mg} / \mathrm{L})$ were low at the two seasons compared with the WHO standards (Table 1). The concentrations of the heavy metals studied fall within the WHO minimum standards except for exceedingly high levels of iron ( $\mathrm{Fe}$ ) in samples SE 5 and SE 6 with values 0.79 and $0.58 \mathrm{mg} / \mathrm{LFe}$ respectively. These values were approximately equal to the maximum permissible limit for iron $(1.0 \mathrm{mg} / \mathrm{L})$. Cobalt also exceeded the WHO limit for daily intake allowance $(0.01 \mathrm{mg} / \mathrm{d})$ with a mean range of 0.01 $0.10 \mathrm{mg} / \mathrm{L}$. The lead $(\mathrm{Pb})$ level was below detection limit. Cadmium, iron and Manganese whose mean concentrations approximated to their guideline limits constitute potential threats to health. There were no significant seasonal variations across the heavy metal ions studied. 
Am. J. Sci. Ind. Res., 2013, 4(2): 231-237

Table 1: Hydro-chemical data on the Mean Concentration of Trace and Heavy Metals (mg/L) in the Spring Water samples at the rainy and dry Seasons.

\begin{tabular}{|c|c|c|c|c|c|c|c|c|c|c|c|c|}
\hline \multicolumn{2}{|c|}{ Metals } & SE1 & SE2 & SE3 & SE4 & SE5 & SE6 & SE7 & $\mathrm{WHO}$ & Mean $\pm S d$ & Range & VC \\
\hline \multirow[t]{2}{*}{$\mathrm{Ca}$} & RS & 4.0 & 3.6 & 2.4 & 7.2 & 7.4 & 0.4 & 0.3 & 200 & $3.60 \pm 2.90$ & $0.3-7.4$ & 0.81 \\
\hline & DS & 5.6 & 5.6 & 2.8 & 7.2 & 7.2 & 0.4 & 0.4 & & $4.17 \pm 2.97$ & $0.4-7.2$ & 0.71 \\
\hline \multirow[t]{2}{*}{$\mathrm{Mg}$} & RS & 1.8 & 1.5 & 0.6 & 2.4 & 0.6 & 0.21 & 0.18 & 150 & $1.04 \pm 0.86$ & $0.21-1.8$ & 0.83 \\
\hline & DS & 6.68 & 10.0 & 3.4 & 2.4 & 0.6 & 0.21 & 0.18 & & $3.35 \pm 3.70$ & $0.18-10.0$ & 1.11 \\
\hline \multirow[t]{2}{*}{$\mathrm{Cd}$} & RS & 0.003 & 0.005 & 0.003 & 0.004 & 0.001 & 0.001 & 0.002 & 0.002 & $0.003 \pm 0.0$ & $\begin{array}{l}0.001- \\
0.005\end{array}$ & 0.0 \\
\hline & DS & 0.002 & 0.004 & 0.003 & 0.004 & 0.001 & 0.001 & 0.002 & & $0.002 \pm 0.001$ & $\begin{array}{l}0.001- \\
0.004\end{array}$ & 0.5 \\
\hline \multirow[t]{2}{*}{ Co } & RS & 0.031 & 0.022 & 0.01 & 0.09 & 0.085 & 0.007 & 0.02 & 0.01 & $0.038 \pm 0.03$ & $0.01-0.09$ & 0.8 \\
\hline & DS & 0.03 & 0.021 & 0.01 & 0.10 & 0.090 & 0.006 & 0.02 & & $0.04 \pm 0.04$ & $0.01-0.10$ & 1.0 \\
\hline \multirow[t]{2}{*}{$\mathrm{Cr}$} & RS & 0.01 & $<0.01$ & 0.01 & $<0.01$ & $<0.01$ & 0.01 & 0.01 & 0.05 & $0.01 \pm 0.0$ & Nil & - \\
\hline & DS & 0.01 & $<0.01$ & $<0.01$ & $<0.01$ & $<0.01$ & 0.01 & 0.01 & & $0.01 \pm 0.0$ & Nil & \\
\hline \multirow[t]{2}{*}{$\mathrm{Cu}$} & RS & 0.01 & 0.02 & 0.04 & 0.02 & 0.025 & 0.01 & 0.03 & 1.0 & $0.22 \pm 0.01$ & $0.01-0.03$ & 0.49 \\
\hline & DS & 0.01 & 0.02 & 0.04 & 0.02 & 0.02 & 0.01 & 0.03 & & $0.020 \pm 0.32$ & $0.01-0.04$ & 0.5 \\
\hline \multirow[t]{2}{*}{$\mathrm{Fe}$} & RS & 0.01 & 0.20 & 0.0 & 0.01 & 0.79 & 0.58 & 0.14 & 0.3 & $0.288 \pm 0.32$ & $0.01-0.79$ & 1.11 \\
\hline & DS & 0.01 & 0.25 & 0.0 & 0.01 & 0.80 & 0.50 & 0.20 & & $0.30 \pm 0.31$ & $0.01-0.80$ & 1.0 \\
\hline \multirow{3}{*}{$\mathrm{Pb}$} & & & & & & & & & & & & \\
\hline & RS & $<0.01$ & $<0.01$ & $<0.01$ & $<0.01$ & 0.01 & 0.01 & 0.01 & 0.01 & $<0.01 \pm 0.0$ & - & 0.0 \\
\hline & DS & $<0.01$ & $<0.01$ & $<0.01$ & $<0.01$ & 0.01 & 0.01 & 0.01 & & $<0.01 \pm 0.0$ & - & 0.0 \\
\hline \multirow[t]{2}{*}{$\mathrm{Mn}$} & RS & 0.16 & 0.01 & 0.01 & 0.01 & 0.10 & 0.02 & 0.01 & 0.05 & $0.046 \pm 0.06$ & $0.01-0.16$ & 1.3 \\
\hline & DS & 0.15 & 0.01 & 0.01 & 0.01 & 0.10 & 0.02 & 0.01 & & $0.04 \pm 0.06$ & $0.01-0.15$ & 1.4 \\
\hline \multirow{3}{*}{$\mathrm{Zn}$} & & & & & & & & & & & & \\
\hline & RS & $<0.001$ & 0.003 & $<0.001$ & 0.003 & 0.01 & 0.02 & 0.01 & & $0.01 \pm 0.01$ & $0.01-0.02$ & 1.0 \\
\hline & DS & 0.006 & 0.003 & $<0.002$ & 0.003 & 0.01 & 0.02 & 0.015 & & $0.01 \pm 0.07$ & $0.02-0.15$ & 0.7 \\
\hline \multirow[b]{2}{*}{$\mathrm{Ni}$} & RS & -0.01 & -0.02 & -0.031 & 0.011 & -0.032 & -0.018 & -0.02 & -0.02 & $-0.02 \pm 0.01$ & $-0.01-0.32$ & -0.5 \\
\hline & DS & -0.01 & -0.02 & -0.031 & 0.011 & -0.032 & -0.018 & -0.02 & & $-0.02 \pm 0.01$ & $-0.01-0.32$ & -0.5 \\
\hline
\end{tabular}

$n=3, D S=$ dry Season, $R S=$ rainy Season, sd=Standard Deviation, Variation Coefficient $(V C)=(s d / x)$ 
The high values of the variation coefficients for the anions (Table 2) indicate that $\mathrm{Cl}^{-}, \mathrm{NO}_{3}{ }^{-}, \mathrm{SO}_{4}{ }^{2-}$ and $\mathrm{PO}_{4}{ }^{3-}$ are widely distributed in ground waters in the area. This suggests that their presence is most likely due to human activities, while the presence of $\mathrm{SiO}_{4}{ }^{4-}$ ions, which variation coefficient was less than unity may be due to natural courses. However, only the $\mathrm{PO}_{4}{ }^{3-}$ concentrations in all the samples studied exceeded the $\mathrm{WHO}$ limits, having a mean range of $0.46 \pm 0.49-0.52 \pm 0.48 \mathrm{mg} / \mathrm{L}$ between the seasons. As a nutrient in natural waters, excessive phosphorous is the main cause of eutrophication.
This may lead to algae blooms and pollution of the water (Miroslav and Vladimir, 1999). The high phosphate level may be attributed to agricultural activities through the application of inorganic fertilizers on farmlands. Components of these fertilizers can leach into groundwater or be carried into spring water cavities through run-offs. It is also suggestive that phosphate rocks, which readily dissolve in acidic water, may be component of the geologic formations..

Table 2: Hydro-chemical data on the Mean Anionic Concentration ( $\mathrm{mg} / \mathrm{L})$ in the spring Water samples at the rainy and dry Seasons

\begin{tabular}{|c|c|c|c|c|c|c|c|c|c|c|c|c|}
\hline \multicolumn{2}{|c|}{ Anions } & SE1 & SE2 & SE3 & SE4 & SE5 & SE6 & SE7 & $\mathrm{WHO}$ & Mean $\pm S d$ & Range & VC \\
\hline \multirow[t]{2}{*}{$\mathrm{Cl}^{-}$} & RS & 14.18 & 14.15 & 8.51 & 2.84 & 5.67 & 6.50 & 4.37 & 250 & $8.03 \pm 4.54$ & $\begin{array}{l}2.84- \\
14.18\end{array}$ & 0.57 \\
\hline & DS & 24.85 & 53.25 & 17.75 & 2.84 & 5.67 & 10.0 & 4.90 & & $17.04 \pm 17.8$ & $\begin{array}{l}2.84- \\
53.25\end{array}$ & 1.04 \\
\hline \multirow[b]{2}{*}{$\mathrm{NO}_{3}^{-}$} & $\mathrm{RS}$ & 0.0 & 0.1 & 0.02 & 0.31 & 0.0 & 0.0 & 0.1 & 50 & $0.08 \pm 0.11$ & $0.0-0.31$ & 1.38 \\
\hline & DS & 0.0 & 0.0 & 0.0 & 0.31 & 0.0 & 1.76 & 0.44 & & $0.36 \pm 0.64$ & $0.0-1.76$ & 1.78 \\
\hline \multirow[b]{2}{*}{$\mathrm{SiO}_{4}{ }^{4-}$} & RS & 8.0 & 6.0 & 8.0 & 18.0 & 16.0 & 17.0 & 15.0 & 40 & $12.57 \pm 5.03$ & $6.0-18.0$ & 0.40 \\
\hline & DS & 7.15 & 5.8 & 8.0 & 18.0 & 16.0 & 16.8 & 14.9 & & $12.38 \pm 5.17$ & $5.8-18.0$ & 0.42 \\
\hline \multirow[t]{2}{*}{$\mathrm{SO}_{4}{ }^{2-}$} & $\mathrm{RS}$ & 15.34 & 27.72 & 34.22 & 0.0 & 0.0 & 1.0 & 3.0 & 200 & $11.61 \pm 14.4$ & $\begin{array}{l}0.0- \\
34.22 \\
\end{array}$ & 1.24 \\
\hline & DS & 14.98 & 26.14 & 30.85 & 0.0 & 0.0 & 0.0 & 3.0 & & $10.71 \pm 13.3$ & $\begin{array}{l}0.0- \\
30.85\end{array}$ & 1.24 \\
\hline \multirow[t]{2}{*}{$\mathrm{PO}_{4}{ }^{3-}$} & $\mathrm{RS}$ & 1.60 & 0.25 & 0.30 & 0.25 & 0.50 & 0.4 & 0.35 & 0.1 & $5.52 \pm 0.48$ & $\begin{array}{l}0.25- \\
1.60\end{array}$ & 0.92 \\
\hline & DS & 1.55 & 0.26 & 0.28 & 0.23 & 0.47 & 0.2 & 0.25 & & $0.46 \pm 0.49$ & $0.2-1.57$ & 1.07 \\
\hline
\end{tabular}

The more serious problem observed of these water sources was the acidic nature of the spring water. The $\mathrm{pH}$ of the samples ranged from 4.2-5.6 at the rainy season and 4.5-6.0 during the dry seasons with a mean range of $5.1 \pm 0.48-5.6 \pm 0.58$ (Table 3 ). This showed a mean seasonal variation of $9 \%$ during the dry seasons. This is undesirable for water meant for drinking according to the $\mathrm{WHO}$, which recommended $\mathrm{pH}$ of $6.5-8.5$. The effect of $\mathrm{pH}$ change of a system by $1 \%$ is as dramatic in changing the quality of water as a $1^{\circ} \mathrm{C}$ change in temperature in chemical reactions. At low $\mathrm{pH}$, dissolution / absorption of toxic substances increase especially in high carbonate and low silicate soils. It promotes colour intensity, affects alkalinity, TDS, $\mathrm{CO}_{2}$ absorption and total coliform presence (Gerard, 1998; Ming-HO, 2001 and Lecherallein et-al, 1996). Besides, prolonged intake of this water may predispose one to the dangers of acidosis, which according to Health Experts may lead to cancer or cardiovascular damage including the constriction of blood vessels and reduction in oxygen supply even at mild levels, (Ogundipe and Obinna, 2008). It can also leach out valuable minerals such as $\mathrm{K}, \mathrm{Mg}, \mathrm{Na}$ and $\mathrm{Ca}$ from the body. 
Am. J. Sci. Ind. Res., 2013, 4(2): 231-237

Table 3: Physiochemical data of the Spring Water samples during the rainy and dry Seasons

\begin{tabular}{|c|c|c|c|c|c|c|c|c|c|c|c|c|}
\hline \multicolumn{2}{|c|}{ Parameter/Samples } & SE1 & SE2 & SE3 & SE4 & SE5 & SE6 & SE7 & WHO & Mean $\pm S d$ & Range & VC \\
\hline \multirow[t]{2}{*}{ Temp $\left({ }^{\circ} \mathrm{C}\right)$} & RS & 27.5 & 28.6 & 27.3 & 29.0 & 29.5 & 25.4 & 26.3 & $10-25$ & $27.7 \pm 1.48$ & $\begin{array}{l}25.4- \\
29.5\end{array}$ & 0.05 \\
\hline & DS & 29.0 & 30.0 & 28.0 & 31.4 & 31.5 & $26 . .0$ & 27.0 & & $29.0 \pm 2.12$ & $26-31.5$ & 0.07 \\
\hline \multirow[t]{2}{*}{$\begin{array}{l}\text { Colour } \\
\text { (Hazen) }\end{array}$} & RS & 5.0 & 5.0 & 5.0 & 102 & 110 & 6.0 & 20 & $5-50$ & $36.1 \pm 48.0$ & 5-110 & 1.33 \\
\hline & DS & 5.0 & 5.0 & 5.0 & 102 & 110 & 5.0 & 5 & & $33.1 \pm 49.34$ & $5-110$ & 1.46 \\
\hline \multirow{2}{*}{$\mathrm{pH}$} & $\mathrm{RS}$ & 5.1 & 5.0 & 5.4 & 5.5 & 5.6 & 4.9 & 4.2 & $6.5-8.5$ & $5.1 \pm 0.48$ & $4.2-5.6$ & 0.09 \\
\hline & DS & 6.0 & 5.8 & 6.0 & 6.0 & 6.0 & 5.2 & 4.5 & & $5.6 \pm 0.58$ & $4.5-6.0$ & 1.04 \\
\hline \multirow[t]{2}{*}{ EC } & $\mathrm{RS}$ & 48 & 98 & 54 & 40 & 38 & 52 & 34 & $500-$ & $52 \pm 21.6$ & $34-98$ & 0.42 \\
\hline & DS & 362 & 368 & 309 & 93 & 68 & 50 & 41 & 1250 & $184.4 \pm 153.5$ & $41-368$ & 0.83 \\
\hline \multirow{2}{*}{$\begin{array}{l}\text { Turbidity } \\
\text { (NTU) }\end{array}$} & $\mathrm{RS}$ & 5 & 10 & 5 & 180 & 195 & 5 & 2 & 25 & $57.4 \pm 89.0$ & $5-195$ & 1.55 \\
\hline & DS & 4 & 6 & 3 & 180 & 195 & 10 & 2 & & $57.1 \pm 89.2$ & $2-195$ & 1.56 \\
\hline \multirow[t]{2}{*}{ TDS(mg/L) } & $\mathrm{RS}$ & 26 & 48.8 & 27.2 & 25 & 18.8 & 26.2 & 17.3 & $1000-$ & $27.4 \pm 10.4$ & $\begin{array}{l}17.3- \\
48.8\end{array}$ & 0.38 \\
\hline & DS & 180 & 181 & 150 & 45 & 32 & 25 & 20.4 & 1500 & $90.5 \pm 75.8$ & $\begin{array}{l}20.4- \\
181\end{array}$ & 0.84 \\
\hline \multirow[t]{2}{*}{$\mathrm{TSS}(\mathrm{mg} / \mathrm{L})$} & RS & 17.2 & 22.4 & 19.2 & 412 & 390 & 15.2 & 18.4 & - & $127.80 \pm 186.8$ & $\begin{array}{l}15.2- \\
412\end{array}$ & 1.46 \\
\hline & DS & 540 & 628 & 920 & 395 & 390 & 28.0 & 16.9 & & $416.84 \pm 322.8$ & $\begin{array}{l}16.9- \\
920\end{array}$ & 0.77 \\
\hline \multirow[t]{2}{*}{$\mathrm{TS}(\mathrm{mg} / \mathrm{L})$} & $\mathrm{RS}$ & 43.2 & 71.2 & 46.4 & 437 & 408.8 & 41.4 & 35.7 & - & $154.81 \pm 183.7$ & $\begin{array}{l}35.7- \\
437\end{array}$ & 1.19 \\
\hline & DS & 720 & 801 & 1070 & 440 & 422 & 53 & 36.5 & & $506.1 \pm 384.7$ & $\begin{array}{l}36.5- \\
1070\end{array}$ & 0.76 \\
\hline \multirow[t]{2}{*}{$\begin{array}{l}\text { Total alkalinity } \\
(\mathrm{mg} / \mathrm{L})\end{array}$} & $\mathrm{RS}$ & 6.0 & 8.0 & 7.0 & 10.0 & 12.0 & 30.0 & 25.0 & 100 & $14.0 \pm 9.5$ & $6-30$ & 0.68 \\
\hline & DS & 43.8 & 6.1 & 146.4 & 11.0 & 12.0 & 28.0 & 24.0 & & $38.76 \pm 49.2$ & $\begin{array}{l}6.1- \\
146.4\end{array}$ & 1.27 \\
\hline \multirow{2}{*}{$\begin{array}{l}\text { Total } \\
\text { Hardness } \\
(\mathrm{mg} / \mathrm{L})\end{array}$} & $\mathrm{RS}$ & 16.0 & 14.0 & 8.0 & 26.0 & 20.0 & 19.6 & 16.5 & 100 & $17.16 \pm 5.60$ & $8-26.0$ & 0.33 \\
\hline & DS & 19.0 & 16.0 & 8.0 & 23.0 & 23.0 & 19.6 & 16.0 & & $17.80 \pm 5.20$ & $8-23.0$ & 0.30 \\
\hline \multirow[t]{2}{*}{$\begin{array}{l}\text { Ca-hardness } \\
(\mathrm{mg} / \mathrm{L})\end{array}$} & RS & 10.0 & 9.0 & 6.0 & 18.0 & 18.0 & 11.0 & 10.0 & 75 & $11.71 \pm 4.57$ & $6-18$ & 0.39 \\
\hline & DS & 12.0 & 9.0 & 5.0 & 17.0 & 19.0 & 11.2 & 10.5 & & $11.96 \pm 4.74$ & $5-19$ & 0.40 \\
\hline \multirow{2}{*}{$\begin{array}{l}\text { Mg-hardness } \\
(\mathrm{mg} / \mathrm{L})\end{array}$} & $\mathrm{RS}$ & 7.0 & 7.0 & 3.0 & 8.0 & 4.0 & 8.4 & 5.5 & 30 & $6.13 \pm 2.04$ & $3-8.4$ & 0.33 \\
\hline & DS & 7.0 & 7.0 & 3.0 & 6.0 & 4.0 & 4.0 & 5.5 & & $5.21 \pm 1.58$ & $3-7.0$ & 0.3 \\
\hline
\end{tabular}


The results of the hardness levels also reveal that the spring water is very soft. The range of $8-26$ $\mathrm{mgCaCO}_{3} / \mathrm{L}$ obtained from this study fall within the 0 $-60 \mathrm{mgCaCO} / \mathrm{L}$ classified by the U.S-EPA as soft water (Miroslav and Vladimir, 1999; Encyclopedia of Chem. Tech.). Soft water has been linked with incidence of cardiovascular diseases.

The concentration of colour was between $36.1 \pm 48$ $33.1 \pm 49.3$ Hazen at the rainy and dry seasons respectively. The mean range of the TDS was $27.4 \pm$ $10.4-90.5 \pm 75.8 \mathrm{mg} / \mathrm{L}$, total solids ranged from $154.8 \pm 183.7-506.1 \pm 384.7 \mathrm{mg} / \mathrm{L}$ and total hardness $(T . H)$ ranged from $17.16 \pm 5.6-17.80 \pm 5.2$ $\mathrm{mg} / \mathrm{L}$ (Table 3 ) at the rainy and dry seasons. These parameters together with the levels of total alkalinity $(14.0 \pm 9.5-38.8 \pm 49.2 \mathrm{mg} / \mathrm{L})$, conductivity $(52 \pm$ $21.6-184.4 \pm 153.5 \mu \mathrm{s} / \mathrm{cm})$, DO $(2.34 \pm 1.1-2.40 \pm$ 1.3) and the 5-Day biochemical oxygen demand, $\mathrm{BOD}_{5}(0.35 \pm 0.1-0.40 \pm 0.1)$ (Table 4), are also within the $\mathrm{WHO}$ highest desirable and maximum permissible limits, indicating the water to be of good quality.

However, samples SE 4 and SE 5 showed turbidity range of $180-195$ NTU. This escalated the mean turbidity range at $57.4 \pm 89.0-57.1 \pm 89.2$ NTU. The two samples also showed excessive colour concentrations of 102 and 110 Hazen respectively. It is possible that the geologic constitution of this area is responsible for the high turbidity level. The soil type of Ohaozara area is marshy, porous and of weathered rocks. This may have equally influenced the turbidity and colour of the spring water in the affected areas. Highly turbid waters serve as breeding places for disease-causing pathogens and algae growth.

The total coliform bacteria count ranged between 0 4 in the rainy season and $0-3$ in the dry season. These values are however very small compared with results obtained from similar studies in recent times (Ofoma et-al, 2005). The level of coliform contamination of the spring water was found to be 40 $\%$ with mean concentration range of $1.2 \pm 1.8-1.0 \pm$ 1.4 (Table 4). The average obtained for five samples in this study (SE 1- 5) exceeded the WHO permissible value of 0 MPN / $100 \mathrm{ml}$ of drinking water. It represents pollution, most likely from sewage as well as solid waste discharge during runoffs. There are no indications of feacal pollution as none of the samples showed the presence of E-Coli. Two of these Springs, SE 4 and SE 5 dries up during the dry seasons. The other three perennial sources from Ekoli Edda in Afikpo South, which are very clean in out-look are not well protected and poorly cared for. This predisposes these sources to bacteria contamination.

Table 4: Bio-chemical data of the Spring Water samples in the study Area at the Rainy and Dry Seasons

\begin{tabular}{|c|c|c|c|c|c|c|c|c|c|c|c|c|}
\hline \multicolumn{2}{|c|}{ Parameters } & SE1 & SE2 & SE3 & SE4 & SE5 & SE6 & SE7 & WHO & Mean \pm sd & Range & $\mathrm{VC}$ \\
\hline \multirow{2}{*}{$\begin{array}{l}\mathrm{DO} \\
(\mathrm{mg} / \mathrm{l})\end{array}$} & RS & 1.8 & 1.6 & 1.6 & 4.3 & 2.5 & 3.2 & 1.4 & & $2.34 \pm 1.07$ & $1.4-4.3$ & 0.46 \\
\hline & DS & 1.6 & 1.5 & 1.4 & 4.6 & 2.6 & 3.6 & 1.5 & 4 & $2.40 \pm 1.26$ & $1.4-4.60$ & 0.53 \\
\hline \multirow[b]{2}{*}{$\%$ DO } & RS & 18 & 16 & 15 & 56 & 30 & 38 & 15 & & $26.86 \pm 15.6$ & $15-56$ & 0.58 \\
\hline & DS & 17 & 16 & nd & 59 & 30 & 42 & 18 & - & $30.33 \pm 17.28$ & $16-59$ & 0.57 \\
\hline \multirow{2}{*}{$\mathrm{BOD}_{5}$} & RS & 0.2 & 0.3 & nd & 0.5 & 0.4 & nd & nd & $\begin{array}{l}0.75- \\
1.5\end{array}$ & $0.35 \pm 0.13$ & $0.2-0.5$ & 0.37 \\
\hline & DS & 0.3 & 0.4 & nd & 0.5 & 0.4 & nd & nd & & $0.40 \pm 0.08$ & $0.3-0.5$ & 0.20 \\
\hline \multirow{2}{*}{$\begin{array}{l}\text { Plate } \\
\text { Count }\end{array}$} & RS & 37 & 18 & 22 & 183 & 100 & nd & nd & & $72 \pm 70.3$ & $18-183$ & 0.98 \\
\hline & DS & 35 & 14 & 21 & 180 & 96 & nd & nd & - & $69.2 \pm 69.9$ & $14-180$ & 1.01 \\
\hline \multirow[t]{2}{*}{$\begin{array}{l}\text { Total } \\
\text { Coliform }\end{array}$} & RS & 4 & 0 & 0 & 0 & 2.0 & nd & nd & $\begin{array}{l}0 / 100 \\
\mathrm{ml}\end{array}$ & $1.2 \pm 1.79$ & $0-4$ & 1.50 \\
\hline & $\mathrm{DS}$ & 3 & 0 & 0 & 0 & 2.0 & nd & nd & & $1.0 \pm 1.41$ & $0-3$ & 1.41 \\
\hline \multirow[b]{2}{*}{ E-Coli } & RS & $-v e$ & -ve & $-v e$ & $-v e$ & $-v e$ & nd & nd & 0 & $-v e$ & - & 0 \\
\hline & DS & $-v e$ & $-v e$ & $-v e$ & $-v e$ & $-v e$ & nd & nd & & -ve & - & 0 \\
\hline
\end{tabular}




\section{CONCLUSION:}

The spring water supply sources are not safe for human consumption per say with regards to high acidity, softness, high phosphate levels and total coliform bacteria contents. Some level of treatment, such as liming is required to rid the water of high acidity.

\section{RECOMMENDATIONS:}

Spring water is acknowledged as the best potable water especially if it is free from chemical contaminants. The source of the spring waters can be protected by housing it and passing PVC pipes inbetween the rock cavities and collecting the water into sedimentation tanks, where liming, disinfection and aeration can be effected. The overflow of the treated spring water can then be passed through distribution pipes to household taps or public consumer taps. This will disallow accessing the water from cavities in which animal droppings, dead vegetations, run-off and other forms of anthropogenic source contaminations observed in this study can no longer affect.

\section{REFERENCES}

Chessbraugh, M (2002). District Laboratory Practice in Tropical Countries Part $\mathrm{H}, 2^{\text {nd }}$ Edu. Cambridge University Press pp. 143-147
Encyclopedia of Chemical Technology $2^{\text {nd }}$.Edition. Vol. 21 p.693

Gerard. K. (1998). Environmental Engineering, Irwin/ McGraw-Hill Book Company, Singapore pp.456

Lecherallein, M.W; Welch, N.J and Smith, D.B (1996). Fullscale study of Factors related to Coliform regrowth in Drinking Water. Applied and Environmental Microbiological Journal 1 (62): p.2201.

Ming-HO, YU (2001). Environmental Toxicology, Impact of Environmental Toxicants on Living Systems. Lewis Publishers, London. pp.49, 151

Miroslav, R and Vladimir, N.B. (1999). Practical Environmental Analysis, Royal Society of Chemistry, U.K pp. 152, 175

Nwajuaku, A.I; Egboka, B.C.E and Orajaka, I.P (1991). Exploration of Groundwater in Fractured Shales of Abakaliki and Environs, An M.Sc. Thisis Report presented to the Dept. of Geological Sciences, NAU. Awka

Ofoma, A. E; Onwuka, D. S and Egbu, O. C (2005). Groundwater quality in Lekwesi / Umuohieze Area, South Eastern Nigeria In: The Pacific Journal of Science and Technology, 6 (2):170-175.

Ogundipe, S and Obinna, C (2008). "Safety of Table Water goes beyond the bottle" In: Good Health Weekly, Vanguard Newspapers Tuesday, May 20, 2008 p.42. River Basin. J. Hydrological Sciences, London.

WHO, (1973). Community Water Supply and Sewage Disposal in Developing Countries, World Health Statistical Report 26(11) Geneva

WHO 1997. Guideline Standards for Drinking Water Quality, $2^{\text {nd }}$ Edition Vol.3. Surveillance and Control of Community Supplies WHO, Geneva 